\title{
PENGARUH PENCAHAYAAN DAN RIWAYAT MEROKOK TERHADAP KEJADIAN PENYAKIT TUBERKULOSIS DIWILAYAH KERJA UPT PUSKESMAS TEMINDUNG KOTA SAMARINDA TAHUN 2018
}

\author{
Apriyani $^{1}$, Eko Mujianto ${ }^{2}$, Muhammad Habibi ${ }^{3}$ \\ riri.apri14491@gmail.com ${ }^{1}$, ekomujianto3592@gmail.com ${ }^{2}$, abhie.go2014@gmail.com ${ }^{3}$ \\ Universitas Widya Gama Mahakam
}

\begin{abstract}
ABSTRAK
Tuberkulosis merupakan masalah kesehatan terbesar di dunia.Indonesia menempati urutan kedua kasus tuberkulosis tertinggi di dunia pada tahun 2016 setelah India.Penelitian ini bertujuan untuk mengetahui pengaruh kondisi fisik rumah dan riwayat merokok terhadap kejadian penyakit tuberkulosis di wilayah kerja UPT Puskesmas Temindung Samarinda. Penelitian ini menggunakan pendekatan studi Case Control dengan total sampel sebanyak 48 responden dimana kelompok kasus sebanyak 24 responden dan kelompok kontrol sebanyak 24 responden. Hasil analisis regresi logistik sederhana menunjukkan bahwa tingkat pencahayaan $(p=0,023)$ dengan $O R=4,048$ dan riwayat merokok $(p=0,009)$ dengan $O R=3,244$. Dapat disimpulkan faktor-faktor yang berpengaruh terhadap kejadian penyakit tuberkulosis adalah tingkat pencahayaan dan riwayat merokok.Diharapkan masyarakat dapat melakukan kebiasaan membuka jendela setiap pagi hari untuk menjaga pencahayaan, kelembaban dan suhu dalam keadaan optimal serta meningkatkan pengetahuan mengenai syarat dan manfaat rumah sehat, tuberkulosis dan bahaya merokok melalui penyuluhan yang dilakukan oleh puskesmas.
\end{abstract}

Kata kunci: tuberculosis, pencahayaan, riwayat merokok

\section{ABSTRACT}

Tuberculosis is considered as the biggest health problem in the world. In 2016, Indonesia is ranked at the second position with the highest number of cases in Tuberculosis in the world, after India. This study is aimed to find out the effect of house's physical condition and its history of smoking toward Tuberculosis disease, especially in UPT Puskesmas Temindung Samarinda. This study applied case control design, employing 48 respondents as the research samples, who were distributed into two groups; case group and control group (24 respondents for each). The result of simple logistic regression shows that the lighting level $(p=0.23)$ with OR=4.048 and the history of smoking $(p=0,009)$ with $O R=3,244$. It can be concluded that factors influencing the appearance of tuberculosis case are the level of lighting and smoking history. Therefore, it is suggested to people to routinely open the windows every morning to keep the lighting, humidity and room temperature at optimal condition. It is also recommended to gain more information about terms and usefulness of healthy house, tuberculosis, and the danger of smoking through counseling carried out by the public health unit.

Key words: Tuberculosis, lighting, history of smoking 
p-ISSN 2460-0350

e-ISSN 2477-5819

JURNAL KESMAS UWIGAMA

\section{PENDAHULUAN}

\section{A. Latar Belakang}

Tuberkulosis (TB) terjadi disetiap bagian dunia. Pada tahun 2016, jumlah kasus tuberkulosis baru terbesar di dunia terjadi di Asia yaitu sebanyak 45\% kasus baru. Kemudian diikuti oleh Afrika sebanyak 25\% kasus baru. Pada tahun 2016 87\% kasus tuberkulosis baru terjadi di 30 negara, Indonesia merupakan Negara dengan jumlah kasus baru terbanyak kedua di dunia setelah India. Kasus tuberkulosis tertinggi terjadi di tujuh negara dengan presentasi kasus sebanyak $64 \%$ kasus antara lain adalah India, Indonesia, China, Filipina, Pakistan, Nigeria, dan Afrika Selatan. Kematian akibat tuberkulosis diperkirakan sebanyak 1,4 juta kematian ditambah 0,4 juta kematian akibat tuberkulosis pada orang dengan HIV. Meskipun jumlah kematian akibat tuberkulosis menurun sebanyak 22\% antara tahun 2000 dan 2015, tuberkulosis tetap menjadi 10 penyebab kematian tertinggi di dunia pada tahun 2015 (WHO, Global Tuberculosis Report, 2016).

Menurut data terbaru Profil Kesehatan Indonesia (2017) penemuan kasus tuberkulosis yaitu sebanyak 360.770 kasus, meningkat bila dibandingkan dengan kasus pada tahun 2016. Kasus tertinggi yang dilaporkan terdapat di Provinsi Jawa Barat sebanyak 78.698 kasus, Jawa Timur 48.323 kasus dan Jawa Tengah 42.272 sedangkan Kalimantan Timur 5.489 kasus. Data-data ini menunjukkan bahwa angka morbiditas akibat tuberkulosis meningkat dari tahun ke tahun.

Faktor penyebab kejadian penyakit tuberkulosis di Indonesia adalah perumahan padat, kumuh, ruangan yang sirkulasi udaranya kurang baik dan cahaya matahari yang kurang. Bakteri penyebab tuberkulosis bisa hidup tahan lama di ruangan berkondisi gelap, lembap, dingin, dan tidak memiliki ventilasi yang baik. Oleh karena itu pembangunan rumah tempat tinggal yang memenuhi syarat kesehatan harus selalu
Volume 4, Nomor 2, 2018

diperhatikan agar setiap ruangan yang ada didalam rumah mendapatkan pergantian aliran udara yang bersih dan mendapatkan pencahayaan matahari yang cukup sehingga risiko terjadinya penyakit yang disebabkan oleh kualitas udara yang buruk dapat dikurangi (Permenkes RI, 2016).

Penelitian di Kota Surabaya kecamatan Mulyorejo oleh Kenedyanti \& Sulistyorini (2017) menyimpulkan bahwa Kondisi fisik rumah (pencahayaan dan kelembaban) yang tidak memenuhi syarat memiliki risiko untuk terjadinya TB paru 3 kali lebih besar dibandingkan dengan kondisi fisik rumah yang memenuhi syarat.Penelitian lainnya yang dilakukan wanti et al (2015), Sari (2016) dan Azzahra (2016) mengatakan bahwa kondisi fisik rumah seperti padatnya hunian rumah, pencahayaan yang kurang dan tidak adanya jendela pada rumah memliki hubungan yang signifikan dengan kejadian penyakit tuberkulosis paru

Kebiasaan merokok juga merupakan penyumbang risiko terserang tuberkulosis. Menurut Permenkes RI (2016) perilaku merokok memiliki risiko terkena tuberkulosis paru sebanyak 2,2 kali lebih besar dibandingkan orang yang tidak merokok.Merokok sebagai faktor penyebab terjadinya tuberkulosis (TB) paru dibuktikan oleh beberapa penelitian antara lain oleh Lalombo, Palendeng \& Kallo (2015) dan Romlah (2015) menyimpulkan bahwa kebiasaan merokok memiliki hubungan dengan kejadian tuberkulosis paru-paru. Penelitian di Pakistan yang dilakukan oleh Batool dkk (2017) pada 311 pekerja sebagai responden, menyebutkan bahwa pekerja yang merokok memiliki 8 kali resiko terinfeksi tuberkulosis dibandingkan dengan pekerja yang tidak merokok.

Menurut Profil Kesehatan Kalimantan Timur (2017) jumlah penemuan kasus baru TB pada tahun 2013 sebesar 2.416 orang, pada tahun 2014 turun menjadi 1.953 orang dan kembali meningkat pada tahun 2015 sebesar 
2.391 orang dan menurun pada tahun 2016 menjadi 2.383 temuan kasus baru TB BTA(+). Jumlah kasus TB BTA(+) tertinggi Pada tahun 2016 di wilayah Kalimantan timur ada pada Kabupaten Kota Samarinda dan Balikpapan tercatat bahwa kasus TB BTA(+) dari dua kabupaten tersebut sama tingginya yaitu berjumlah 457 kasus. Menurut data terbaru dari Profil Kesehatan Indonesia (2017) jumlah penemuan kasus TB BTA(+) di Provinsi Kalimantan Timur mengalami peningkatan daripada tahun sebelumnya yaitu sebesar 2.425 orang.

Di Kota Samarinda, TB paru merupakan masalah kesehatan lama yang masih tetap ada sampai saat ini. Berdasarkan laporan dari Dinas Kesehatan Kota Samarinda (2017) pada tahun 2016 dari 4.098 suspek TB, terdapat penderita tuberkulosis paru yaitu sebanyak 819 kasus dan pada tahun 2017 dari 3.303 suspek TB, terdapat penderita tuberkulosis paru yaitu sebanyak 693 kasus. Dan kasus tuberkulosis paru tertinggi di Kota Samarinda pada tahun 2017 ditempati oleh UPT Puskesmas Temindung yang memliki wilayah kerja di kelurahan Sungai Pinang Dalam dan Mugirejo yaitu sebanyak 57 kasus .

$$
\text { Unit Pelaksana Teknis (UPT) }
$$

Puskesmas Temindung Samarinda merupakan bagian dari Dinas Kesehatan Kabupaten Kota Samarinda yang bertanggung jawab menyelenggarakan pembangunan kesehatan kepada masyarakat di 2 Kelurahan yaitu Sungai Pinang Dalam dan Mugirejo. Berdasarkan data terbaru dari UPT Puskesmas Temindung, sampai dengan bulan Juni 2018 tercatat kasus tuberkulosis paru yaitu sebanyak 43 orang.

Berdasarkan uraian latar belakang, teori, jurnal dan data-data diatas terkait Tuberkulosis (TB) maka penulis tertarik untukmelakukan penelitian tentang Pengaruh Kondisi Fisik Rumah dan Riwayat Merokok Terhadap Kejadian Penyakit Tuberkulosis di Wilayah Kerja UPT Puskesmas Temindung Kota Samarinda.

\section{B. Rumusan Masalah}

Berdasarkan pada uraian latar belakang diatas, maka rumusan masalah dalam penelitian ini adalah bagaimana pengaruh antara pencahayaan dan riwayat merokok dengan kejadian penyakit Tuberkulosis di wilayah kerja UPT Puskesmas Temindung Samarinda?

\section{Metode Penelitian}

Jenis penelitian yang digunakan adalah kuantitatifdengan desain kasus kontrol atau Case control. Adapun populasi dalam penelitian ini Jumlah populasi kasus tuberkulosis paru adalah 43 penderita tuberkulosis dan 43 orang sehatdengan menggunakan metode Total Sampling (sampel diambil seluruhnya) dimana perbandingan antara kelompok kasus (penderita tuberkulosis paru dan kontrol (orang sehat) sama besar jumlahnya (1:1). Jadi, target sampel dalam penelitian ini adalah 43 penderita tuberkulosis paru dan 43 orang sehat.

Akan tetapi, pada saat penelitian dilapangan sampel yang terkumpul yaitu hanya 24 kasus dan 24 kontrol dikarenakan pada kelompok kasus yaitu sebanyak 10 orang telah selesai pengobatan selama 6 bulan, 2 orang dibawah 15 tahun, 2 orang meninggal dunia, 1 orang pindah alamat rumah, 1 orang tidak dikunjungi karena alasan keamanan peneliti, 3 orang tidak dapat ditemui ditempat pada saat penelitian berlangsung, 2 orang alamat rumah dan nomor handphone tidak jelas, 2 orang tidak dapat dihubungi dan 1 orang tidak dikunjungi dikarenakan terlalu berisiko (responden merupakan penderita TB MDR).Sehingga responden yang berpartisipasi pada penelitian ini yaitu sebanyak 24 responden kasus dan 24 responden kontrol.

Teknik pengumpulan data dengan menggunakan lembar kuesioner dan lembar observasi.Lembar kuesioner digunakan untuk mengetahui identitas responden, status pengobatan dan riwayat merokok responden sedangkan lembar observasi digunakan untuk 
mengobservasi dan mencatat rata-rata hasil pengukuran yang meliputi tingkat pencahayaan rumah responden yang diukur menggunakan alat Luxmeter.

\section{HASIL DAN PEMBAHASAN}

\section{Karakteristik Responden}

Karakteristik responden yang dilihat dalam penelitian ini adalah jenis kelamin dan umur yang terdapat pada tabel dibawah ini:

Tabel 1. Karakteristik Responden Berdasarkan Jenis Kelamin

\begin{tabular}{ccc}
\hline Jenis Kelamin & Jumlah (n) & Persentase (\%) \\
\hline Laki-laki & 26 & 54 \\
Perempuan & 22 & 46 \\
\hline Total & $\mathbf{4 8}$ & $\mathbf{1 0 0}$ \\
\hline
\end{tabular}

Tabel 2. Karakteristik Responden Berdasarkan Umur

\begin{tabular}{ccc}
\hline Kelompok Umur & Jumlah (n) & Persentase (\%) \\
\hline $15-21$ & 3 & 6,3 \\
$22-28$ & 7 & 14,6 \\
$29-35$ & 9 & 18,8 \\
$36-42$ & 11 & 22,9 \\
$43-49$ & 6 & 12,5 \\
$50-56$ & 9 & 18,8 \\
$57-63$ & 2 & 4,2 \\
$64-67$ & 1 & 2 \\
\hline Total & $\mathbf{4 8}$ & $\mathbf{1 0 0}$ \\
\hline
\end{tabular}

Berdasarkan tabel 1 menunjukkan bahwa dari 48 responden $54 \%$ responden adalah laki-laki dan $46 \%$ responden adalah perempuan. Berdasarkan tabel 2 karakteristik umur, persentase kelompok umur paling tinggi adalah kelompok 36 - 42 tahun yaitu 22,9\%.

\section{Analisis Univariat}

Berdasarkan hasil analisis univariat, diperoleh hasil sebagai berikut:
Tabel 3.Distribusi Frekuensi Tingkat Pencahayaan

\begin{tabular}{lccccc}
\hline $\begin{array}{c}\text { Tingkat } \\
\text { Pencahayaan }\end{array}$ & Kontrol & $(\boldsymbol{\%})$ & Kasus & $(\boldsymbol{\%})$ & $\begin{array}{c}\text { Juml } \\
\text { ah }\end{array}$ \\
\hline $\begin{array}{l}\text { Memenuhi } \\
\text { Syarat }\end{array}$ & 17 & 70,8 & 9 & 37,5 & 26 \\
$\begin{array}{l}\text { Tidak } \\
\text { Memenuhi } \\
\text { Syarat }\end{array}$ & 7 & 29,2 & 15 & 62,5 & 22 \\
\hline \multicolumn{1}{c}{ Total } & $\mathbf{2 4}$ & $\mathbf{1 0 0 \%}$ & $\mathbf{2 4}$ & $\mathbf{1 0 0}$ & $\mathbf{4 8}$ \\
\hline
\end{tabular}

Dapat dilihat bahwa responden tuberkulosis pada kelompok kasus yang memiliki tingkat pencahayaan rumah yang tidak memenuhi syarat yaitu sebanyak 15 reponden $(62,5 \%)$ dan yang memenuhi syarat yaitu sebanyak 9 responden (37,5\%). Berdasarkan tabel 3 dapat disimpulkan bahwa sebanyak 22 rumah responden memiliki tingkat pencahayaan yang tidak memenuhi syarat sedangkan 26 rumah responden memiliki tingkat pencahayaan yang memenuhi syarat.

Tabel 4. Distribusi Frekuensi Riwayat Merokok

\begin{tabular}{lccccc}
\hline $\begin{array}{c}\text { Riwayat } \\
\text { Merokok }\end{array}$ & Kontrol & $(\boldsymbol{\%})$ & Kasus & $\mathbf{( \% )}$ & $\begin{array}{c}\text { Jum } \\
\text { lah }\end{array}$ \\
\hline & & & & & \\
Bukan & 20 & 83,3 & 9 & 37,5 & 29 \\
Perokok & 2 & 8,3 & 8 & 33,3 & 10 \\
Perokok & 2 & 8,3 & 3 & 12,5 & 5 \\
Perokok & 0 & 0 & 4 & 16,7 & 4 \\
\hline Total & $\mathbf{2 4}$ & $\mathbf{1 0 0 \%}$ & $\mathbf{2 4}$ & $\mathbf{1 0 0 \%}$ & $\mathbf{4 8}$ \\
\hline
\end{tabular}

Dapat dilihat bahwa responden tuberkulosis pada kelompok kasus yang memiliki riwayat merokok sebagai perokok berat yaitu sebanyak 8 reponden (33,3\%), perokok sedang sebanyak 3 responden $(12,5 \%)$, perokok ringan sebanyak 4 responden (16,7\%) dan bukan perokok sebanyak 9 responden (37,5\%).Berdasarkan tabel 4 responden yang memiliki riwayat merokok yaitu sebanyak 19 orang. 


\section{Analisis Bivariat}

Berdasarkan hasil uji analisis uji variabel independen terhadap variabel dependen menggunakan ujiRegresi Logistik Sederhana, diperoleh hasil sebagai berikut:

\section{a. Pengaruh Tingkat Pencahayaan Terhadap Kejadian Penyakit Tuberkulosis}

Tabel 5. Pengaruh Tingkat Pencahayaan Terhadap Penyakit Tuberkulosis

\begin{tabular}{cccccc}
\hline Pencahayaan & Kontrol & Kasus & Jumlah & $\boldsymbol{p}$ & OR \\
\hline MS & 17 & 9 & 26 & 0,02 & 4,04 \\
TMS & 7 & 15 & 22 & 3 & 8 \\
\hline Total & $\mathbf{2 4}$ & $\mathbf{2 4}$ & $\mathbf{4 8}$ & & \\
\hline
\end{tabular}

Berdasarkan tabel 5 menunjukkan bahwa tingkat pencahayaan dalam rumah pada kelompok kasus yang tidak memenuhi syarat (60 lux-250 lux) yaitu sebanyak 15 responden $(62,5 \%)$ dan yang memenuhi syarat $(<60$ lux atau >250 lux) yaitu sebanyak 9 responden $(37,5 \%)$. Secara statistik hasil analisa dengan menggunakan uji Regresi Logistik Sederhana menunjukkan nilai $p=0,023$ dan $\mathrm{OR}=4,048$ dengan tingkat kepercayaan CI : 95\% (1,210 13,538). Karena nilai $p<0,05$ maka Ho ditolak dan Ha diterima, sehingga dapat disimpulkan bahwa terdapat pengaruh antara tingkat pencahayaan terhadap kejadian penyakit tuberkulosis. Responden yang tingkat pencahayaan rumahnya tidak memenuhi syarat, berisiko 4 kali lebih tinggi terkena penyakit tuberkulosis dibanding responden yang tingkat pencahayaan rumahnya memenuhi syarat.

Dari hasil penelitian tentang kondisi fisik rumah yang berpengaruh terhadap kejadian tuberkulosis, menunjukkan bahwa tingkat pencahayaan memiliki pengaruh yang signifikan terhadap kejadian penyakit tuberkulosis di wilayah kerja UPT Puskesmas Temindung Kota Samarinda. Penelitian ini sejalan dengan penelitian terdahulu yang dilakukan oleh Azzahra (2017) yang menyimpulkan bahwa terdapat hubungan antara pencahayaan dan kejadian penyakit tuberkulosis dan diperkuat oleh penelitian
Tobing (2015) yang menyatakan terdapat pengaruh yang signifikan antara pencahayaan terhadap kejadian tuberkulosis.

Menurut temuan pada penelitian, kebiasaan responden menutup jendela juga mempengaruhi kurangnya intensitas cahaya yang dapat masuk ke dalam setiap sudut rumah, sehingga dapat memicu rumah dalam keadaan kelembaban yang tinggi dimana kondisi ini dapat menjadi media untuk perkembangan bakteri yang merugikan kesehatan penghuninya. Menurut Peraturan Menteri Kesehatan RI No. 67 Tahun 2016 Tentang Penanggulangan Tuberkulosis pencahayaan matahari yang bagus untuk mengurangi kelembaban ruangan yaitu minimal 60 Lux atau lebih selain itu pada tingkat pencahayaan tersebut sudah memiliki sifat bakterisida alami dikarenakan kandungan sinar ultravioletnya.

Faktor lainnya yang menyebabkan kurangnya intensitas cahaya yang masuk ke dalam ruangan yaitu kondisi ventilasi rumah responden yang masih kurang dari $10 \%$ dari luas lantai. Ventilasi bukan hanya sekedar tempat bertukarnya udara dari dalam dan luar rumah, akan tetapi juga memiliki fungsi sebagai jalan masuknya cahaya matahari kedalam rumah. Cahaya masuk melalui celah lubang ventilasi sehingga ruangan dalam rumah menjadi nyaman dan tidak lembab.

Dari hasil penelitian ditemukan bahwa rumah responden pada kelompok kasus dengan kondisi jendela rumah yang tertutup yaitu sebanyak 17 rumah $(70,8 \%)$ sedangkan yang kondisi jendela rumahnya terbuka yaitu sebanyak 7 rumah (29,2\%). Diantara responden kelompok kasus juga ditemukan jenis jendela kaca permanen terdapat pada 4 rumah responden dan 1 responden kondisi rumahnya tidak memiliki jendela. 


\section{b. Pengaruh Riwayat Merokok Terhadap Kejadian Tuberkulosis}

Tabel 6. Pengaruh Riwayat Merokok Terhadap Penyakit Tuberkulosis

\begin{tabular}{cccccc}
\hline $\begin{array}{c}\text { Riwayat } \\
\text { Merokok }\end{array}$ & Kontrol & Kasus & Jumlah & $\boldsymbol{p}$ & OR \\
\hline Bukan & 20 & 9 & 29 & & \\
Perokok & 2 & 8 & 10 & 0,0 & 3,244 \\
Berat & 2 & 3 & 5 & 09 & \\
Sedang & 0 & 4 & 4 & & \\
Ringan & $\mathbf{2 4}$ & $\mathbf{2 4}$ & $\mathbf{4 8}$ & & \\
\hline Total & $\mathbf{2 4}$ & & & &
\end{tabular}

Berdasarkan tabel 6 menunjukkan bahwa responden tuberkulosis pada kelompok kasus yang memiliki riwayat merokok sebagai perokok berat yaitu sebanyak 8 reponden $(33,3 \%)$, perokok sedang sebanyak 3 responden $(12,5 \%)$, perokok ringan sebanyak 4 responden (16,7\%) dan bukan perokok sebanyak 9 responden (37,5\%). Secara statistik hasil analisa dengan menggunakan uji Regresi Logistik Sederhana menunjukkan nilai $p=$ 0,009 dan $\mathrm{OR}=3,244$ dengan tingkat kepercayaan CI : 95\% (1,345 - 7,826). Karena nilai $p<0,05$ maka Ho ditolak dan Ha diterima, sehingga dapat disimpulkan bahwa ada pengaruh antara riwayat merokok terhadap kejadian penyakit tuberkulosis. Responden yang memiliki riwayat merokok berisiko 3,2 kali lebih tinggi terkena penyakit tuberkulosis dibanding responden yang tidak memiliki riwayat merokok.

Berdasarkan hasil penelitian yang telah dilakukan dapat disimpulkan bahwa riwayat merokok (perokok berat) memiliki pengaruh yang signifikan terhadap kejadian penyakit tuberkulosis di wilayah kerja UPT Puskesmas Temindung Kota Samarinda. Penelitian ini sesuai dengan penelitian terdahulu yang dilakukan oleh Batool dkk (2017) yang menyatakan terdapat hubungan yang signifikan antara riwayat merokok terhadap kejadian tuberkulosis dimana nilai signifikansinya yaitu $p=0,000<0,05$.

Pada penelitian ini dilakukan dengan memberikan beberapa pertanyaan kepada responden seperti; sejak usia berapa menghisap rokok, dalam sehari menghabiskan berapa batang rokok dan kapan terakhir berhenti merokok. Dari hasil wawancara kemudian dilakukan scoring dengan menggunakan Indeks Brinkman. Perhitungan Indeks Brinkman yaitu perkalian antara jumlah rata-rata batang rokok yang dihisap dalam sehari dikalikan lama merokok dalam tahun kemudian dari hasil perkalian tersebut, dikategorikan kedalam 4 kategori antara lain bukan perokok, perokok ringan, perokok sedang dan perokok berat.

Berdasarkan tabel 6 memaparkan sebanyak 9 responden termasuk kategori bukan perokok akan tetapi 9 responden tersebut merupakan penderita tuberkulosis hal ini dikarenakan faktor lain seperti 1 penderita tuberkulosis mengidap penyakit lain yaitu diabetes. Menurut Mihardja (2015) penderita diabetes berisiko terkena tuberkulosis 1,5 - 8,9 kali dibanding orang tanpa diabetes, hiperglikemia pada penderita diabetes dapat menurunkan respon imunologik sehingga memudahkan terjadinya infeksi tuberkulosis. Hal ini sesuai dengan pernyataan yang dikeluarkan oleh World Health Organization (WHO) 2018 bahwa selain merokok, tuberkulosis juga dapat terjadi karena host menderita penyakit diabetes.

Menurut informasi yang didapatkan pada saat penelitian terdapat 2 responden yang bekerja di malam hari. Responden-responden tersebut tidak merokok akan tetapi terkena penyakit tuberkulosis diduga dikarenakan lingkungan tempat kerja mereka yang mayoritasnya perokok aktif. Kesimpulan ini didapatkan dari wawancara dengan responden dan keluarga responden. Menurut Mario (2010) mengatakan asap rokok dapat meningkatkan risiko terinfeksi kuman Mycobacterium tuberculosis. Asap rokok mengandung lebih dari 4.500 bahan kimia yang memiliki berbagai efek racun, mutagenik dan karsinogenik. Zat-zat ini memiliki efek proinflamasi dan imunosupresif pada sistem 
imun saluran pernafasan, sehingga dapat meningkatkan risiko infeksi Mycobacterium tuberculosis. Sehingga baik perokok, mantan perokok dan perokok pasif dapat meningkatkan risiko terkena penyakit tuberkulosis (Sayuti,2013).

Kebiasaan merokok merupakan penyumbang risiko terserang tuberkulosis. Menurut Permenkes RI (2016) perilaku merokok memiliki risiko terkena tuberkulosis paru sebanyak 2,2 kali lebih besar dibandingkan orang yang tidak merokok. Berdasarkan penelitian Wuaten (2010) dalam lalombo (2015) menyimpulkan bahwa merokok setiap hari akan mempercepat penumpukan toksin dalam paru-paru dan meningkatkan risiko terkena penyakit tuberkulosis sebanyak 2,2 kali lebih besar dibanding orang yang tidak merokok setiap hari.

Selain merokok setiap hari, perilaku merokok di dalam rumah merupakan faktor penyebab buruknya kualitas udara dalam rumah karena bahan-bahan kimia dari rokok dapat mengeluarkan polutan yang dapat bertahan dalam rumah untuk jangka waktu yang cukup lama.Hal ini menyebabkan kualitas udara bersih di dalam rumah menjadi minim dan zat polutan dapat mengiritasi paruparu, sehingga sistim pertahanan paru-paru terhadap kuman dan patogen menjadi lemah (Permenkes RI, 2011).

\section{SIMPULAN}

1. Tingkat pencahayaan rumah dibawah 60 Lux berpengaruh terhadap kejadian penyakit tuberkulosis dan berisiko 4 kali lipat untuk terkena penyakit tuberkulosis dibanding rumah yang tingkat pencahayaannya diatas 60 Lux.

2. Seseorang yang memiliki riwayat merokok (perokok berat, sedang, ringan) berpengaruh terhadap kejadian penyakit tuberkulosis dan berisiko 3,2 kali lipat untuk terkena penyakit tuberkulosis dibandingkan seseorang yang bukan perokok.

\section{DAFTAR PUSTAKA \\ Buku/Literatur:}

Azzahra, Zira. (2017). "Faktor-Faktor Yang Mempengaruhi Kejadian Penyakit Tuberkulosis Paru di Wilayah Kerja Puskesmas Mulyorejo Kecamatan Sunggal Kabupaten Deli Serdang Tahun 2017”. Skripsi Fakultas Kesehatan Masyarakat. Universitas Sumatera Utara Medan.

Batool, Aima Iram et al. (2016). Study Of Tuberculosis Associated Workplace Risk Factors Among Coal Miners. Journal Of Entomology and Zoology Studies 2017, 5(1): 609-614, E-ISSN: 2320-7078 P-ISSN: 2349-6800. Pakistan.

Dinas Kesehatan Kalimantan Timur.(2017). Profil Kesehatan Tahun 2016. Samarinda: Dinkes Kaltim.

Kementerian Kesehatan RI. (2018). Profil Kesehatan Indonesia Tahun 2017. Jakarta: Kemenkes RI.

Kenedyanti, Evin \& Sulistyorini, Lilis.(2017).

Analisis Mycobacterium Tuberkulosis Dan Kondisi Fisik Rumah Dengan Kejadian Tuberkulosis Paru. Open Access Under CC BY-SA. Universitas Airlangga. Surabaya.

Lalombo Alfah Yulied, Palandeng Henry \& Kallo Vanry D. (2015). Hubungan Kebiasaan Merokok Dengan Kejadian Tuberkulosis Paru di Puskesmas Siloam Kecamatan Tamako Kabupaten Kepulauan Sangihie.Ejournal Keperawatan (e-kep), Volume 3.Manado.

Peraturan Menteri Kesehatan RI No. 67 Tahun 2016 Tentang Penanggulangan Tuberkulosis.

Peraturan Menteri Kesehatan RI Nomor 1077/Menkes/Per/V/2011 Tentang Pedoman Penyehatan Udara Dalam Ruang Rumah. 
Romlah, Laila. (2015). "Hubungan Merokok Dengan Kejadian Penyakit Tuberkulosis Paru Di Wilayah Kerja Puskesmas Setu Kota Tangerang Selatan'.Skripsi Fakultas Kedokteran Dan Ilmu Kesehatan. Universitas Islam Negeri Syarif Hidayatullah. Jakarta.

Sari, Anis Ratna. (2016). "Hubungan Antara Sanitasi Rumah Dengan Kejadian TB Paru Pada Ana Di Wilayah Kerja Puskesmas Wedung 1 Kabupaten Demak'.Skripsi Fakultas Ilmu Keolahragaan. Universitas Negeri Semarang.

Sayuti, Jalaludin. (2013). Asap Sebagai Salah Satu Faktor Risiko Kejadian TB Paru BTA Positif. Seminar Nasional Informatika Medis (SNIMed) IV,p.13,2013. Magister Teknik Informatika. Fakultas Teknologi Industri. Universitas Islam Indonesia.

Tobing, Lumban T, (2015). Pengaruh Penderita TB Paru dan Kondisi Fisik Rumah Terhadap Pencegahan Potensi Penularan TB Paru Pada Keluarga di Kabupaten Tapanuli Utara Tahun
2015.Tesis Program Pasca Sarjana. Universitas Sumatera Utara.

UPT Puskesmas Temindung.2017. Laporan Bulanan Program TB Bulan Oktober Tahun 2017.Samarinda. 2017.

Vindrahapsari, Rizka Tiara. (2016). Kondisi Fisik Dan Jumlah Bakteri Udara Pada Ruangan AC dan Non AC di Sekolah Dasar Sang Timur Semarang. Skripsi Fakultas Kesehatan Masyarakat. Universitas Muhammadiyah Semarang.

Wanti et al. (2015). Relationship Between House Condition And Tuberculosis Incidence In Timor Tengah Utara District. International Journal of Science: Basic and Applied Research (IJSBAR) ISSN 2307-4531 (2015) Vol. 21 No. 1, pp 344-349.

World Health Organization (WHO).(2016). WHO Global Tuberculosis Report 2016.http://www.who.int/tb/data/en/ ,Diakses pada tanggal 19 Januari 2018.

World Health Organization (WHO). (2018). Key Facts About Tuberculosis. http://www.who.int/news-room/factsheets/detail/tuberculosis, diakses pada 07 Juni 2018. 